\title{
Effects of Vitamin A Supplementation on Plasma Retinol Concentrations, Fertility and Milk Yield of Dairy Cows
}

\author{
Hajime KUMAGAI, Yot CHAIPAN and Katsunosuke MITANI ${ }^{1}$ \\ Graduate School for International Development and Cooperation, Hiroshima University, \\ Higashihiroshima-shi 739-8529, Japan \\ ' Faculty of Applied Biological Science, Hiroshima University, \\ Higashihiroshima-shi 739-8528, Japan
}

(Received July 9, 1999 ; Accepted November 10, 1999)

\begin{abstract}
Effects of vitamin A supplementation during the dry period and early lactation on vitamin A status, milk yield and reproductive performance of dairy cows were studied. Eleven primiparous and 10 multiparous Holstein Friesian cows were assigned into one of three groups : 1) control ; 2) $700,000 \mathrm{IU}$ of vitamin A supplemented in diet at weekly intervals from 30 days before expected calving ; 3) 700,000 IU of vitamin A supplemented in diet at weekly intervals from 60 days before expected calving. The supplementation was done by mixing with concentrate weekly and lasted for 45 days after calving. Vitamin A supplementation slightly increased the plasma retinol concentrations of cows 1 day after calving. The supplementation had no significant effect on days to first service, days open and services per conception of cows. The supplementation 60 days before the expected calving significantly decreased milk yield 5 and 15 days after calving. The plasma retinol concentrations of multiparous cows were significantly lower than those of primiparous cows 45 and 90 days after calving. The plasma retinol concentrations of cows 90 days after calving were negatively correlated with milk yield of the same length period after calving. 700,000 IU of vitamin A supplemented in diet at weekly intervals from 60 days before calving might have an adverse effect on the milk yield at the beginning of lactation. The lower plasma retinol concentrations of multiparous cows at the peak of lactation were due to large transfer of vitamin A into milk.
\end{abstract}

Animal Science Journal 71 (2): 143-149, 2000

Key words : Vitamin A, Plasma retinol concentrations, Dairy cows, Milk yield, Reproductive performance

Vitamin $\mathbf{A}$ is an essential nutrient for health and performance of animals and the deficiency in pregnant cows results in shortened gestation periods and a high incidence of retained placenta ${ }^{9}$. Recent interest in the role of vitamin $\mathrm{A}$ in fertility has focused upon various reproductive functions including ovarian function, vaginal and uterine epithelium and immune systems. Several studies indicated that dairy cattle secreted a large amount of vitamin A into colostrum and milk during early lactation period ${ }^{8,15 !}$. Recently, genetic improvement for dairy cows have provided them the ability to produce high milk yield. Rations for such high producing dairy cows consists of concentrate, silage, hay and food processing by-products instead of green pasture. Generally, $\beta$-carotene concentrations in hay and silage harvested at late ripening stage or exposed to sunlight were much lower than that in forage fed green. Thus attention should be paid to provitamin $\mathrm{A}$ and vitamin $\mathrm{A}$ contents in diets fed and vitamin A status of peripartrient high producing dairy cows.

Several studies have indicated that higher level of dietary vitamin $\mathrm{A}$ and $\beta$-carotene before calving improved reproductive performance and milk

Corresponding : Hajime KUMAGAI (fax : +81 (0) 824-24-6929, e-mail : hkuma@ipc.hiroshima-u.ac.jp) 
KUMAGAI, CHAIPAN and MITANI

Table 1. Chemical composition of the diets used

\begin{tabular}{|c|c|c|c|c|c|c|c|c|}
\hline & $\begin{array}{l}\text { Dry } \\
\text { matter }\end{array}$ & $\begin{array}{l}\text { Crude } \\
\text { protein }\end{array}$ & $\begin{array}{l}\text { Crude } \\
\text { fiber }\end{array}$ & $\begin{array}{l}\text { Ether } \\
\text { extract }\end{array}$ & $\begin{array}{l}\text { Crude } \\
\text { ash }\end{array}$ & NFE & $\begin{array}{l}\text { Vitamin } \\
\text { A }\end{array}$ & $\beta$-carotene \\
\hline & $(\%)$ & \multicolumn{5}{|c|}{$\longrightarrow$ ( $\%$ on a DMbasis $)$} & \multicolumn{2}{|c|}{ (IU/kg on a DM basis) } \\
\hline Concentrate $\mathrm{A}^{1.2}$ & 88.8 & 15.6 & 10.2 & 1.9 & 5.7 & 66.7 & 433 & 172 \\
\hline Concentrate $\mathrm{B}^{2}$ & 89.0 & 15.1 & 6.7 & 3.9 & 9.6 & 64.7 & 433 & 160 \\
\hline Concentrate $\mathrm{C}^{2}$ & 95.5 & 35.2 & 7.4 & 7.6 & 5.8 & 44.0 & 333 & 148 \\
\hline Beet pulp & 94.9 & 10.3 & 17.3 & 0.3 & 7.0 & 65.0 & $\mathrm{ND}^{3}$ & 120 \\
\hline Sudangrass hay & 93.7 & 9.6 & 33.0 & 1.3 & 9.1 & 46.7 & ND 1 & 1,704 \\
\hline Alfalfa hay & 89.6 & 18. 9 & 37.5 & 5.4 & 8.4 & 29.7 & ND & 636 \\
\hline Italian ryegrass hay & 88.8 & 12.1 & 33.1 & 1.9 & 7.7 & 45.3 & ND 4 & 4,920 \\
\hline Maize silage & $30.6 \pm 2.4^{4}$ & $9.2 \pm 0.3$ & $21.1 \pm 2.2$ & $1.8 \pm 0.2$ & $61.1 \pm 1.6$ & $61.1 \pm 1.6$ & ND 7 & $7,640 \pm 3,360$ \\
\hline
\end{tabular}

'Fed to cows before calving.

${ }^{2}$ Fed to cows after calving.

${ }^{3}$ Not detected.

${ }^{4}$ Means of 6 samples and STD.

production of cows ${ }^{2,11,16}$. However, relationship between effects of period and amount of supplementation and performance of cows is complicated. Oldham et al. ${ }^{11)}$ reported that cows supplemented with $170,000 \mathrm{IU}$ vitamin A per day, as compared with $50,000 \mathrm{IU}$ per day, from 75 days before the expected calving to 42 days after calving improved milk yield of cows but had no effect on udder health. Tharnish and Larson ${ }^{17}$ rcported that supplementation of $1,000,000 \mathrm{IU}$ vitamin A per day, as compared with 100,000 IU per day, during the first 120 days postpartum did not improve the fertility of cows.

The present study was conducted to investigate the effects of periparturient vitamin A supplementation at two levels of supplementation period on vitamin A status of cows, fertility and milk yield. As the requirement and practical supplementation being taken into consideration, 700,000 IU vitamin A was mixed with diet at weekly intervals.

\section{Materials and Methods}

\section{Animals and diets}

Eleven primiparous and ten multiparous Holstein Friesian cows from Experimental Farm of Hiroshima University were studied from May 1995 to February 1996. The liveweight of primiparous and multiparous cows was $558 \pm 35 \mathrm{~kg}$ and $643 \pm 45 \mathrm{~kg}$ (mean \pm
STD), respectively immediately before calving. The cows calved from July to November 1995. The primiparous cows were fed with $2 \mathrm{~kg}$ concentrate per day per head and with Sudangrass hay ad libitum for 60 days before expected calving (Table 1). The multiparous cows were dried 60 days before expected calving. They were fed with $2 \mathrm{~kg}$ each of concentrate and Italian ryegrass hay per day per head and with maize silage ad libitum. The cows were fed with 19 $\mathrm{kg}$ maize silage, $1 \mathrm{~kg}$ beet pulp, $1.3 \mathrm{~kg}$ Italian ryegrass hay, $1.5 \mathrm{~kg}$ alfalfa hay and 8 to $21 \mathrm{~kg}$ concentrate according to the total digestible nutrient (TDN) and crude protein (CP) requirement of dairy cattle ${ }^{1)}$ for 90 days after calving. The cows were milked at 0800 and $1600 \mathrm{~h}$ immediately before morning and evening feeding. The cows were placed on the breeding list at 30 days postpartum.

\section{Treatment}

Primiparous and multiparous cows were assigned into one of three groups as follows : 1) control group (4 primiparous and 3 multiparous cows), 2) 700,000 IU of retinol palmitate (Rovimix A-500, Japan-Roche Inc.) were supplemented in diet at weekly intervals from 30 days before expected calving ( $\mathrm{s} .30$ group, 4 primiparous and 3 multiparous cows) and 3) 700,000 IU of retinol palmitate were supplemented in diet at weekly intervals from 60 days before expected calving 
(s.60 group, 3 primiparous and 4 multiparous cows). The supplementation lasted for 45 days after calving. The supplementary vitamin $\mathrm{A}$ was blended into the concentrate.

\section{Sampling and analysis}

Liveweight of cows was measured within 5 days before and within $12 \mathrm{~h}$ after parturition. Milk yield of cows was weighed at every milking. Blood samples were collected from the jugular vein by using heparinized vacuum tubes on $60,45,30,15$ and 5 days before expected calving and on 1, 5, 15, 45 and 90 days after calving. The blood was centrifuged at 3,000 $\mathrm{rpm}$ for $15 \mathrm{~min}$ and plasma was stored at $-30^{\circ} \mathrm{C}$ until analysis for retinol.

Hay, beet pulp and concentrate samples were taken once and those of silage were taken 6 times during the experimental period. The samples were partly stored at $-30^{\circ} \mathrm{C}$ for $\beta$-carotene and retinol analyses and the rests were used for other chemical analyses.

Concentrations of retinol and $\beta$-carotene were measured by the methods of Katsui ${ }^{5,6)}$ and Olmedilla et al. ${ }^{12)}$, respectively. Briefly, $1 \mathrm{ml}$ plasma samples were deproteinized using $1 \mathrm{~m} l$ ethanol containing $1 \%$ pyrogallol and extracted with n-hexane. One gram milled or finely cut diet samples were homogenized in $10 \mathrm{ml}$ ethanol with $6 \%$ pyrogallol. One milliliter $60 \% \mathrm{KOH}$ was added to saponify the homogenate and extracted with $\mathbf{n}$-hexane. The hexane extract was evaporated by purging with nitrogen and the residue was redissolved in $300 \mu l$ methanol with $0.1 \%$ butylated hydroxytoluene. The concentrations of retinol and $\beta$-carotene were determined by using highperformance liquid chromatography (HPLC).

\section{Statistics}

Plasma retinol concentrations, liveweight loss before and after calving, services per conception, days to first service, days open, and milk yield were analysed by analysis of variance (ANOVA) using General Linear Models (GLM) procedure in Statisitical Analysis System (SAS) program package ${ }^{14)}$. The mathematical model was

$\mathrm{Y}=\mu+\mathrm{Si}+\mathrm{Pj}+(\mathrm{SP}) \mathrm{ij}+\mathbf{E i j k}$

Where

$\mu=$ overall mean

$\mathrm{Si}=$ effect associated with treatment groups
$P j=$ effect associated with parity

(SP) $\mathrm{ij}=$ interaction effect between treatment and parity

Eijk $=$ residuals

Multiple regression equations to estimate milk yield, services per conception, days to first service and days open were developed by stepwise method.

\section{Results}

One primiparous cow from the control group and 2 multiparous cows from the s. 30 and s.60 groups were culled from 5 to 44 days after calving because of low milk yield, gangrenous mastitis and dislocation of the hip joint, respectively.

The retinol concentrations in plasma of cows are shown in Table 2. Vitamin A supplementation for the s.30 and s.60 groups started at 36-23 and 64-48 days before calving, respectively. The plasma retinol concentrations were lower at 11-3 days before calving and 1 day after calving in all groups than the other stages, however, the concentrations recovered during the first 15 days postcalving. Although the levels of plasma retinol of cows in the 5.30 and s.60 groups were significantly higher than those in the control group on 1 day after parturition $(\mathrm{P}=0.09)$, the difference was small. The plasma retinol concentrations of multiparous cows were significantly lower than those of primiparous cows 45 and 90 days after calving $(P<$ 0.05 ).

The fertility and milk yield of cows in the experiment is presented in Table 3. No significant differences of liveweight loss at calving, services per conception, days to first service and days open in the treatment groups were observed. The milk yield 5 and 15 days after calving of cows in the control group was significantly higher than those in the s.60 group $(P<$ 0.05 ). The milk yield 15,45 and 90 days after calving of multiparous cows was significantly higher than that of primiparous cows $(\mathbf{P}<0.05)$.

The correlation coefficient between plasma retinol concentrations and performances of cows is shown in Table 4. Negative correlation coefficient between weight loss at calving and plasma retinol concentrations 90 days after calving was observed $(\mathrm{r}--0.45)$. The services per conception and plasma retinol con- 
KUMAGAI, CHAIPAN and MITANI

Table 2. Effects of vitamin A supplementation and parity on plasma retinol concentrations of cows $(\mu \mathrm{g} / \mathrm{d} l)$

\begin{tabular}{|c|c|c|c|c|c|c|c|c|c|}
\hline & \multicolumn{2}{|c|}{ Control } & \multicolumn{2}{|c|}{ s. $30^{1}$} & \multicolumn{2}{|c|}{ s. $60^{2}$} & \multicolumn{3}{|c|}{ Significance } \\
\hline & $\begin{array}{c}\text { Primiparous } \\
\text { cows }\end{array}$ & $\begin{array}{l}\text { Multiparous } \\
\text { cows }\end{array}$ & $\begin{array}{l}\text { Primiparous } \\
\text { cows }\end{array}$ & $\begin{array}{l}\text { Multiparous } \\
\text { cows }\end{array}$ & $\begin{array}{l}\text { Primiparous } \\
\text { cows }\end{array}$ & $\begin{array}{l}\text { Multiparous } \\
\text { cows }\end{array}$ & Treatment & Parity & $\begin{array}{c}\text { Treatment } \\
\text { parity }\end{array}$ \\
\hline No. of cows & 3 & 3 & 4 & 2 & 3 & 3 & & & \\
\hline \multicolumn{10}{|c|}{ Days before calving } \\
\hline $64-48$ & $27.3 \pm 3.3^{3}$ & $24.1 \pm 7.2$ & $23.0 \pm 5.3$ & $35.3 \pm 7.4$ & $23.1 \pm 1.6$ & $22.7 \pm 5.2$ & NS & NS & $\mathbf{P}=0.05$ \\
\hline $36-23$ & $23.2 \pm 2.3$ & $30.9 \pm 9.3$ & $23.9 \pm 6.0$ & $35.3 \pm 6.6$ & $29.8 \pm 8.1$ & $22.5 \pm 2.6$ & NS & NS & $\mathbf{P}=0.06$ \\
\hline $11-3$ & $17.0 \pm 2.1$ & $20.3 \pm 6.6$ & $21.8 \pm 4.7$ & $23.2 \pm 1.8$ & $24.9 \pm 3.0$ & $17.6 \pm 2.3$ & NS & NS & $P=0.06$ \\
\hline \multicolumn{10}{|c|}{ Days after calving } \\
\hline 1 & $10.9 \pm 2.5$ & $13.9 \pm 3.2$ & $13.8 \pm 4.5$ & $17.7 \pm 2.6$ & $18.2 \pm 5.2$ & $14.9 \pm 2.5$ & $P=0.09$ & NS & NS \\
\hline 5 & $17.2 \pm 1.4$ & $17.1 \pm 4.8$ & $25.6 \pm 12.7$ & $24.5 \pm 9.1$ & $23.4 \pm 5.7$ & $19.6 \pm 16.7$ & NS & NS & NS \\
\hline 15 & $29.8 \pm 5.6$ & $27.9 \pm 5.9$ & $25.9 \pm 2.9$ & $35.1 \pm 4.8$ & $36.2 \pm 2.5$ & $27.6 \pm 15.8$ & NS & NS & NS \\
\hline 45 & $37.1 \pm 1.8$ & $23.7 \pm 6.2$ & $33.7 \pm 3.2$ & $26.9 \pm 3.1$ & $29.2 \pm 7.8$ & $20.2 \pm 4.5$ & NS & $*$ & $\mathbf{P}=0.07$ \\
\hline 90 & $37.6 \pm 8.9$ & $27.4 \pm 12.6$ & $37.9 \pm 2.3$ & $31.2 \pm 4.1$ & $39.7 \pm 3.6$ & $23.5 \pm 4.3$ & NS & * & NS \\
\hline
\end{tabular}

${ }^{1,2}$ From 30 days (1), or 60 days (2) before expected calving until 45 days postcalving, retinol palmitate was supplemented (700,000 IU/week).

${ }^{3}$ Means and STD.

* : $P<0.05$, NS : not significant $(P>0.10)$.

Table 3. Effects of vitamin A supplementation and parity on fertility and milk yield of cows

\begin{tabular}{|c|c|c|c|c|c|c|c|c|c|}
\hline & \multicolumn{2}{|c|}{ Control } & \multicolumn{2}{|c|}{ s. $30^{1}$} & \multicolumn{2}{|c|}{ s. $60^{2}$} & \multicolumn{3}{|c|}{ Significance } \\
\hline & $\begin{array}{c}\text { Primiparous } \\
\text { cows }\end{array}$ & $\begin{array}{c}\text { Multiparous } \\
\text { cows }\end{array}$ & $\begin{array}{c}\text { Primiparous } \\
\text { cows }\end{array}$ & $\begin{array}{c}\text { Multiparous } \\
\text { cows }\end{array}$ & $\begin{array}{c}\text { Primiparous } \\
\text { cows }\end{array}$ & $\begin{array}{c}\text { Multiparous } \\
\text { cows }\end{array}$ & Treatment & Parity & $\begin{array}{c}\text { Treatment } \\
\text { parity }\end{array}$ \\
\hline No. of cows & 3 & 3 & 4 & 2 & 3 & 3 & & & \\
\hline Weight loss at calving $(\%)$ & $7.4 \pm 2.0^{3}$ & $8.8 \pm 2.7$ & $10.2 \pm 0.9$ & $9.3 \pm 3.1$ & $10.0 \pm 3.1$ & $10.9 \pm 0.8$ & NS & NS & NS \\
\hline Services/conception & $1.50 \pm 0.71$ & $2.80 \pm 1.64$ & $2.00 \pm 0.10$ & $02.50 \pm 2.12$ & $1.25 \pm 0.5$ & $3.00 \pm 1.41$ & NS & NS & NS \\
\hline Days to first service & $157 \pm 44$ & $56 \pm 30$ & $53 \pm 1$ & $142 \pm 25$ & $95 \pm 51$ & $115 \pm 64$ & NS & NS & NS \\
\hline Days open & $171 \pm 27$ & $119 \pm 103$ & $165 \pm 126$ & $163 \pm 54$ & $111 \pm 24$ & $157 \pm 62$ & NS & NS & NS \\
\hline \multicolumn{10}{|l|}{ Total milk yield $(\mathrm{kg})$} \\
\hline 5 days after calving & $89 \pm 16$ & $125 \pm 13$ & $82 \pm 14$ & $99 \pm 10$ & $81 \pm 10$ & $79 \pm 38$ & $* 4$ & NS & NS \\
\hline 15 days after calving & $306 \pm 17$ & $153 \pm 41$ & $285 \pm 27$ & $387 \pm 10$ & $301 \pm 24$ & $328 \pm 78$ & $* 4$ & * & NS \\
\hline 45 days after calving & $1,018 \pm 74$ & $1,516 \pm 161$ & $1,039 \pm 75$ & $1,493 \pm 27$ & $1,094 \pm 78$ & $1,317 \pm 276$ & NS & $* *$ & NS \\
\hline 90 days after calving & $2,044 \pm 31$ & $3,068 \pm 382$ & $2,250 \pm 40$ & $3,074 \pm 32$ & $2,280 \pm 169$ & $2,758 \pm 479$ & NS & $* *$ & NS \\
\hline
\end{tabular}

${ }^{1.2}$ From 30 days (1), or 60 days (2) before expected calving until 45 days postcalving, retinol palmitate was supplemented (700,000 IU/week).

${ }^{3}$ Means and STD.

${ }^{4}$ Control vs. $\$ .60$.

$*: \mathrm{P}<0.05,{ }^{*} \mathrm{P}<0.01$, NS : not significant $(\mathrm{P}>0.10)$. 
Table 4. Correlation coefficients between plasma retinol concentrations and reproductive parameters and milk yield of cows

\begin{tabular}{|c|c|c|c|c|c|}
\hline \multirow[t]{2}{*}{ Parameters } & \multicolumn{5}{|c|}{ Plasma retinol concentrations } \\
\hline & $1^{1}$ & 5 & 15 & 45 & 90 \\
\hline Weight loss at calving & 0.17 & -0.21 & -0.21 & -0.19 & -0.45 \\
\hline Services/conception & -0.08 & -0.39 & -0.48 & -0.40 & $-0.63 * *$ \\
\hline Days to first service & 0.01 & -0.03 & 0.17 & 0.41 & 0.19 \\
\hline Days open & -0.15 & -0.36 & -0.24 & 0.08 & -0.39 \\
\hline \multicolumn{6}{|l|}{ Total milk yield } \\
\hline 5 days after calving & -2 & -0.48 & - & - & - \\
\hline 15 days after calving & - & - & -0.38 & - & - \\
\hline 45 days after calving & - & - & - & -0.39 & - \\
\hline 90 days after calving & - & - & - & - & $-0.52 *$ \\
\hline
\end{tabular}

centrations 15,45 and 90 days after calving was negatively correlated. The milk yield 90 days after calving was negatively correlated with plasma retinol concentrations 90 days after calving and the correlation coefficient was significant $(\mathrm{P}<0.05)$.

The results of multiple regression analyses are shown in Table 5. Parity had a positive coefficient and supplementation of vitamin A 60 days before the expected calving had a negative coefficient in the equations (1) and (2). Parity and vitamin A supplementation 60 days before the expected calving were selected as independent valuables of regression equation to estimate milk yield 5 and 15 days after calving. Services per conception was given by the regression equation (5) of which independent valuables were weight loss at calving and milk yield 15 days after calving. Both the independent valuables had positive coefficients.

\section{Discussion}

According to the estimated intake of the diets fed and the concentrations of vitamin $A$ and $\beta$-carotene in the diets, the primiparous cows ingested 13,800 and $55,300 \mathrm{IU} /$ day vitamin A before and after calving, respectively, and the multiparous cows ingested 56,600 and 62,000 IU/day vitamin A before and after calving, respectively, in the control group. Japanese
Feeding Standard ${ }^{1}$ recommended that 45,000 IU/day vitamin $A$ is required for pregnant cows weighing 600 $\mathrm{kg}$ and that 44,700 to $65,900 \mathrm{IU} /$ day vitamin A for cows weighing $600 \mathrm{~kg}$ and lactating 15 to $30 \mathrm{~kg} /$ day. Judging from the requirement, in the control group, the dietary vitamin A was almost sufficient for the multiparous cows before calving and the lactating cows. On the other hand, the dietary vitamin A was insufficient for the primiparous cows before calving.

The plasma retinol concentrations of cows drastically declined around calving date (Table 2). Blood et al. ${ }^{3)}$ reported that the decline of plasma retinol concentration of cows around calving was caused by the uptake of large amount of vitamin $A$ in mammary gland near parturition to supply newborn calves with vitamin $\mathrm{A}$ in colostrum. The difference of plasma retinol concentrations of cows between the control and vitamin A supplemented groups was little even around calving date. It is suggested that vitamin A supplementation had little effect on maintenance of plasma retinol level of cows around calving. The supplemented vitamin A might have been transferred into colostrum and milk as previously observed in the experiment of ewes ${ }^{7}$.

The plasma retinol concentrations of multiparous cows were significantly lower than those of primiparous cows 45 and 90 days after calving (Table 
KUMAGAI, CHAIPAN and MITANI

Table 5. Regression equations for milk yield and reproductive parameters of cows

\begin{tabular}{|c|c|c|c|c|c|c|c|}
\hline \multirow[b]{2}{*}{ Equation number } & \multicolumn{3}{|c|}{ Total milk yield $(\mathrm{kg})$} & \multirow[b]{2}{*}{$\begin{array}{l}90 \\
(4)\end{array}$} & \multirow{2}{*}{$\begin{array}{c}\text { Services/ } \\
\text { conception } \\
\text { (5) }\end{array}$} & \multirow{2}{*}{$\begin{array}{l}\text { Days to } \\
1^{\text {st }} \text { service } \\
(6)\end{array}$} & \multirow{2}{*}{$\begin{array}{c}\text { Days } \\
\text { open } \\
(7)\end{array}$} \\
\hline & $\begin{array}{c}5^{1} \\
(1)\end{array}$ & $\begin{array}{c}15 \\
(2)\end{array}$ & $\begin{array}{l}45 \\
(3) \\
\end{array}$ & & & & \\
\hline Intercept & 94.97 & 323.8 & $1,054.7$ & $2,200.4$ & -3.4840 & 233.69 & 45.23 \\
\hline $\begin{array}{l}\text { Independent valuables } \\
\text { treatment }(\mathrm{s} .60)^{2}\end{array}$ & -20.92 & -480 & & & & & \\
\hline Parity $^{3}$ & 19.58 & 1022 & 405.9 & 7882 & & & \\
\hline Milk yield for 15 days after calving $(\mathrm{kg})$ & -4 & - & - & - & 0.0079 & -0.22 & \\
\hline Weight loss at calving $(\%)$ & & & & & 0.3053 & -5.86 & 9.85 \\
\hline $\mathbf{R}^{2}$ & 0.455 & 0.647 & 0.718 & 0.706 & 0.585 & 0.157 & 0.136 \\
\hline SEE & 1852 & 48.82 & 13406 & 26825 & 0.856 & 5159 & 67.46 \\
\hline $\begin{array}{l}\text { Significance of coefficient of } \\
\text { determination }\end{array}$ & $*$ & $* *$ & $* *$ & $* *$ & $* *$ & NS & NS \\
\hline
\end{tabular}

$\mathbf{R}^{2}$ : ratio of contribution.

SEE : standard error of estimate.

${ }^{1}$ Days after calving.

${ }^{2,3}$ Dummy valuable ; ${ }^{2} \cdot 60=1$ and others $=0,{ }^{3}$ multiparous cows $=1$ and primiparous cows $=0$.

${ }^{4}$ The independent valuables are not used for developing the regression equations.

${ }^{*}: \mathrm{P}<0.05,{ }^{* *}: \mathrm{P}<0.01$, NS : not significant $(\mathrm{P}>0.10)$.

2). Normally, plasma vitamin $\mathbf{A}$ in dairy cows is controlled between 25 and $60 \mu \mathrm{g} / \mathrm{d} l^{1 /}$. It has been found that plasma retinol concentrations must be at least $27 \mu \mathrm{g} / \mathrm{d} l$ to maintain renal function of filtration in maximum level. ${ }^{13)}$ Thus the plasma vitamin A concentrations of multiparous cows 45 and 90 days after calving which werc 23 and $27 \mu \mathrm{g} / \mathrm{d} /$ on an average, respectively, were judged to be similar to the lower limits of normal level. The milk yield 45 and 90 days after calving of multiparous cows was absolutely higher than those of primiparous cows and negative correlation between plasma retinol concentrations and milk yield of cows was observed (Tables 3 and 4). Kume et al. ${ }^{9 /}$ reported that vitamin A concentration of milk in multiparous cow was higher than that in primiparous cows 10 weeks after parturition. It is likely that the lower plasma retinol concentrations of multiparous cows on 45 and 90 days after calving were caused by the transfer of vitamin $\mathrm{A}$ in large amount into the milk.

Little difference of milk yield in primiparous cows among treatment groups was observed, but the milk yield 5 and 15 days after calving in multiparous cows

Anim. Sci. J. 71 (2) : 143-149, 2000 of the 5.60 group was lower than that in multiparous cows of the control group (Table 3 ). In the control group, dietary vitamin A was sufficient for the multiparous cows. Additional $700,000 \mathrm{IU}$ vitamin A was supplemented to cows in $s .60$ group from 60 days before expected calving at weekly intervals. The additional vitamin $\mathrm{A}$ was similar to the maximum tolerable level of vitamin A for dairy cows on the day supplied, which is $66,000 \mathrm{IU}$ per $\mathrm{kg}$ diet on a dry matter basis ${ }^{10)}$, since the dry matter intake of cows was estimated from 10 to $14 \mathrm{~kg}$ before calving. Thus the long term and large amount of vitamin A supplementation might have lowered the milk yield of multiparous cows in the beginning of lactation.

The milk yield 15 days after calving was correlated with services per conception and was selected as an independent valuables of regression equation to estimate services per conception (Table 5). The finding coincides with previous study that negative energy balance resulted from failure of dietary intake to keep pace with rising milk production related to lower conception rate ${ }^{4}$. Negative correlation between plasma retinol concentrations 5, 15, 45 and 90 days 
after calving and services per conception likely reflected the negative correlation between milk yield and plasma retinol concentrations.

In summary, vitamin A supplementation from 60 and 30 days before the expected calving to 45 days after calving had little effect on plasma retinol concentrations and reproductive performances. The plasma retinol concentrations of multiparous cows were significantly lower than those of the primiparous cows 45 and 90 days after calving which might be due to the transfer of vitamin A in large amount into the milk. The supplementation from 60 days before the expected calving decreased the milk yield of multiparous cows 15 days from calving. However characteristic symptoms of hypervitaminosis A were not observed in the animals including the two multiparous cows culled in their early lactation. Further study should be done to investigate the cause of adverse effect of vitamin A supplementation on lactation.

\section{Achnowledgments}

The authors express their appreciation for Rovimix A-500 given by Japan-Roche Inc. Acknowledgment is made to Experimental Farm of Hiroshima University for the technical assistance, advice and cooperation.

\section{References}

1) Agriculture, Forestry and Fisheries Research Council Secretariat. Japanese Feeding Standard for Dairy Cattle. 15-16. Central Association of Livestock Industry. Tokyo. 1994.

2) Ascarelli I, Edelman Z, Rosenberg M, Folman Y. Effect of dietary carotene on fertility of high yielding dairy cows. Animal Production, 40 : 195-207. 1985.

3) Blood DC, Henderson JA, Radostits OH. Diseases caused by nutritional deficiencies. In : Veterinary Medicine : a Textbook of the Diseases of Cattle, Sheep, Pigs and Horses. 921. Lea and Febiger Publisher. Philadelphia. 1979.

4) Butler WR, Smith RD. Interrelationships between energy balance and postpartum reproductive function in dairy cattle. Journal of Dairy Science, $72: 767$ $-783.1989$.

5) Katsui G. Assay methods of vitamin A. 2. Assay methods of vitamin $\mathrm{A}$ in blood and tissue. Vitamin (Japan), $56: 97-101.1982$.
6) Katsui G. Assay methods of vitamin A.3. Assay methods of vitamin $A$ in pharmaceutical preparation, food and feeds by high performance liquid chromatography. Vitamin (Japan), 56: 151-156. 1982.

7) Kumagai $\mathrm{H}$, White $\mathrm{CL}$. The effect of supplementary minerals, retinol and $\alpha$-tocopherol on the vitamin status and productivity of pregnant Merino ewes. Australian Journal of Agricultural Research, 46 : 1159-1174. 1995.

8) Kume S, Yamamoto E, Kudo T, Tanabe S. Effect of parity on mineral and vitamin status of Holstein cows during early lactation. Animal Science and Technology, 66 : 506-512. 1995.

9) McDowcll LR. Vitamins in Animal Nutrition. 1054. Academic Press. San Diego. 1989.

10) National Research Council. Vitamin Tolerance of Animals. 3-10. National Academy of Sciences. Washington, D.C. 1987.

11) Oldham ER, Eberhart RJ, Muller LD. Effects of supplemental vitamin $\mathrm{A}$ or $\beta$-carotene during the dry period and early lactation on udder health. Journal of Dairy Science, 74 : 3775-3781. 1991.

12) Olmedilla B, Granado F, Rojas-Hidalgo E, Blanco I. A rapid separation of ten carotenoids, three retinoids, alpha-tocopherol and D-alpha-tocopherol acetate by high performance liquid chromatography and its application to serum and vegetable sample. Journal of Liquid Chromatography, 13 : 1455-1483. 1990.

13) Richards JI, Bridge PS, Spratling FR, Abrams JT. Renal clearances in normal and vitamin A-deficient twin calves. International Journal for Vitamin and Nutrition Research, 40 : 567-574. 1970.

14) SAS Institute. SAS User's Guide. Statistics. Version 5. 433-506. SAS Institute Inc. Cray, NC. 1985.

15) Schweigert FJ. Effect of gestation and lactation on lipoprotein and composition in dairy cows. Journal of Physiology and Animal Nutrition, 63: 75-83. 1990.

16) Tekpetey FR, Palmer WM, Ingalls JR. Seasonal variation in serum $\beta$-carotene and vitamin $A$ and their association with postpartum reproductive performance of Holstein cows. Canadian Journal of Animal Science, $67: 491-500.1987$.

17) Tharnish TA, Larson LL. Vitamin A supplementation of Holsteins at high concentrations : progesterone and reproductive responses. Journal of Dairy Science, $75: 2375-2381.1992$. 